\title{
ОСНОВНІ ПІДХОДИ ДО ВИЗНАЧЕННЯ КАТЕГОРІЇ «КОРУПЦІЙНІ РИЗИКИ» У СФЕРІ ПРАЦІ
}

Красюк Т. В., Зал Д. О.

у статті сформоване авторське визначення корупційних ризиків у сфері праці, з'ясовано причини низької антикорупційної динаміки у країні, запропоновані можливі шляхи подолання корупційних ризиків. Доведено, що корупційні ризики виступають передумовою для корупції в сфері трудових відносин, а дії законодавия хоча і спрямовані на вдосконалення антикорупційної політики, але наявне нормативне забезпечення наразі не є досконалим та лишається проблемою, що потребує першочергового вирішення.

Ключові слова: корупція, корупційні ризики в сфері праці, антикорупційна політика.

В статье сформировано авторское определение коррупционных рисков в сфере труда, выяснены причины низкой антикоррупционной динамики в стране, предложены возможные пути преодоления коррупционных рисков. Доказано, что коррупционные риски выступают предпосылкой для коррупции в сфере трудовых отношений, а действия законодателя хотя и направлены на совершенствование антикоррупционной политики, но действующее нормативное обеспечение пока не является совершенным и остаётся проблемой, требующей первоочередного решения.

Ключевые слова: коррупчия, коррупчионные риски в сфере труда, антикоррупционная политика.

Corruption, acting as a negative social phenomenon, concerns and influences almost all spheres of human life, flourishes under any legal regime and any government, only its volume in different countries is different. Therefore, we find it extremely urgent to find out the legal nature and essence of the prerequisites for the emergence and existence of corruption - corruption risks.

The author's definition of corruption risks in the world of work is formed in the article, the reasons for the low anti-corruption dynamics in the country are clarified, and possible ways to overcome corruption risks are proposed. It is proved that corruption risks are a prerequisite for corruption in the field of labor relations, and the actions of the legislator, although aimed at improving the anti-corruption policy, the regulatory support is not yet perfect and remains a problem that needs to be addressed first.

The concept of corruption is complex and multifaceted, which should be considered in the complex of the relevant features. In particular, corruption: firstly, it is a system of relations, which includes representatives of all authorities, secondly, it is a certain psychological state of a person associated with viola tion of mandatory rules, thirdly, it is a social-negative phenomenon that affects the functioning of public institutions and, most importantly, the concept of corruption is not reduced to bribery.

The aim of the study is a comprehensive, in-depth analysis of innovations in existing legislation governing legal relations in connection with corruption offenses and offenses related to corruption, the search for existing shortcomings in it and the provision of proposals for their solution, as well as the formation of their own definition of the category of labor risks in sphere of corruption relations.

Key words: corruption, corruption risks in the world of work, anti-corruption policy.

Красюк Т. В., Зал Д. О., 2019
Постановка проблеми. Явище корупції має давню історію, іï витоки сягають ще первісних часів. Відомості про корупцію містяться в багатьох історичних джерелах, зокрема античних і давньосхідних цивілізацій. Протягом тривалого часу корупція існує та процвітає за будь-якого правового режиму та будь-якої влади, відмінним $€$ тільки її обсяг у різних країнах. Корупція, виступаючи як негативне суспільне явище, стосується і впливає майже на всі сфери людського життя. Насамперед високий рівень корупції знижує авторитет країни на міжнародній арені, перешкоджає економічній діяльності держави, знижує показники виробництва, що безпосередньо впливають на рівень іноземних інвестицій. На внутрішньому рівні знижується рівень довіри населення до чинної влади, створюється загроза ведення і функціонування підприємницької діяльності тощо.

Натепер Україна $є$ однією з найкорумпованіших країн світу. Підтвердженням цього $є$ дослідження міжнародної неурядової організації Transparency International, яка щороку надає рейтинг країни за показником корупції та формує місця та бали країн за показником корупції. Так, у 2018 році Україна посіла 120 місце із 180 країн та отримала 32 бали зі 100 можливих [1]. 3 огляду на це справедливо наголосити на тому, що проблема визначення сутності і правової природи корупційних ризиків, механізми, що сприяють їхньому зниженню, $\epsilon$ вкрай актуальними та потребують подальших досліджень.

Стан дослідження. Проблема корупції в усіх виявах, iї причини та методи подолання привертає увагу чималої кількості науковців. Серед них - М. Мельник, М. Хавронюк, С. Серьогін, О. Онищук. Питання корупційних ризиків, їх поняття, класифікація та заходи усунення вивчались такими науковцями, як К. Бугайчук, А. Волошенко; як підставу розірвання трудових відносин корупційне правопорушення розглядали у своїх працях О. Луценко, О. Соколова та ін. У зазначених дослідженнях використовується фундаментальний підхід для вивчення всіх аспектів корупції, а тому вони можуть стати точкою відліку для інших систематичних досліджень цієї проблематики.

Мета дослідження - всебічний, поглиблений аналіз доктринальних підходів до визначення категорії «корупційні ризики», виклад авторських пропозицій щодо вирішення проблематики корупційних ризиків та зменшення їх впливу на трудові відносини.

Виклад основного матеріалу. Дослідження проблеми корупційних ризиків у сфері праці потребує визначення поняття та сутності корупції як суспільно-негативного явища взагалі. Енциклопедії та словники найчастіше говорять, що слово корупція походить від латинського corruptio, що означає псування, розбещування, підкуп [2]. Так, розглядаючи тлумачення поняття «корупція», Словник української мови визначає, що це підкупність, продажність урядовців 


\section{Проблеми трудового права та права соціального забезпечення}

і громадських діячів [3]. У багатомовному юридичному словнику-довіднику корупція розглядається у двох визначеннях: 1) використання посадовою особою свого службового становища з метою особистого збагачення; 2) підкуп і продажність серед державних, політичних і громадських діячів, а також урядовців і службовців державного апарату [4, с. 99-100].

У міжнародних документах корупція визначається по-різному. У резолюції «Практичні заходи боротьби 3 корупцією», поширеній на VIII Конгресі Організації Об'єднаних Націй із запобігання злочинності, термін корупція пов'язується з порушеннями етичного, дисциплінарного, адміністративного характеру, що проявлялися у протизаконному використанні свого службового становища суб'єктом корупційної діяльності [5, с. 9]. Довідковий документ Організації Об'єднаних Націй «Про міжнародну боротьбу з корупцією» визначає ії як зловживання державною владою для одержання вигоди в особистих цілях [5, с. 9-10]. Міждисциплінарна група з корупції Ради Європи надає таке визначення корупції: хабарництво та будь-яка інша винагорода особі, якій доручено виконання певних обов'язків у державному або приватному секторі, що веде до порушень зобов'язань, покладених на неї за статусом державної посадової особи, приватного співробітника, незалежного агента, або іншого роду відносини з метою отримати будь-які незаконні вигоди для себе та інших [5, с. 10].

Таким чином, міжнародні нормативні акти надають підстави для розширення поняття «корупція», виводячи його за межі безпосереднього хабарництва, зокрема, зміст поняття «корупція» доповнюється такими елементами, як вигода для себе та інших, винагорода за відмову від виконання законних службових обов'язків.

Поглиблюючись у правову доктрину, слушно зауважити про чималу кількість наукових дискусій та думок з приводу проблеми визначення сутності та поняття корупції. Так, зокрема, М. Мельник наголошує на тому, що корупція - соціальне явище, зумовлене соціальними закономірностями розвитку та справляє негативний вплив на соціальні процеси. Корупція пронизує всі соціальні сфери суспільства, певним чином деформуючи суспільні відносини [6, с. 20]. Науковець визначає корупцію як спосіб мислення, який зумовлює спосіб життя [6, с. 11].

Слушною $€$ позиція А. Куракіна, яка збігається із висновками щодо корупції, які надані у міжнародних документах. Зокрема, науковець наголошує, що корупція - це соціальне явище, що виявляється в розкладанні суспільства та держави. [7] Не можна не погодитись із думкою С. Серьогіна, який зазначає, що корупція бере свій початок ще із зародження державності й відображає суперечності між недостатністю ресурсів для задоволення власних потреб і прагненням деяких посадових осіб використати власне становище з метою більш повного задоволення особистих потреб та потреб найближчого оточення [8, с. 3].

Беручи до уваги розробки науковців та праці міжнародних організацій, законодавець закріпив поняття корупція на державному рівні, що знайшло своє вираження у Законі України «Про запобігання корупції» від 14.10.2014 р. № 1700-VII. Отже, легальне визначення поняття «корупція» таке: використання особою наданих їй службових повноважень чи пов'язаних з ними можливостей з метою одержання неправомірної вигоди або прийняття такої вигоди чи прийняття обіцянки/пропозиції такої вигоди для себе чи інших осіб, або відповідно обіцянка/пропозиція чи надання неправомірної вигоди особі або на їі вимогу іншим фізичним чи юридичним особам з метою схилити цю особу до протиправного використання наданих їй службових повноважень чи пов'язаних з ними можливостей [9].

Таким чином, можна зробити висновок, що поняття «корупція» $є$ складним і багатогранним, яке потрібно розглядати у комплексі відповідних ознак. Зокрема, корупція: по-перше, $\epsilon$ певною системою відносин, по-друге, певний психологічний стан особи, що пов'язується із порушенням загальнообов'язкових норм, по-третє, $\epsilon$ соціально-негативним явищем, яке впливає на функціонування суспільних інститутів i, найголовніше, поняття корупції не зводиться до хабарництва.

Розглядаючи корупційні ризики безпосередньо в площині трудових відносин, доречно наголосити на тому, що, як правило, корупція для них становить небезпеку перш за все через іï непомітність і неврегульованість. Йдеться, зокрема, про декларативність норм Закону України «Про запобігання корупції». Саме в ньому вперше було застосована категорія «корупційні ризики», проте легальне визначення цього поняття відсутнє. У межах доктрини це поняття визначається по-різному. К. Бугайчук визначає це поняття через дію або стан, що виступає передумовами для вчинення корупційних правопорушень [10, с. 3-4]. К. Заїка розглядає корупційні ризики через призму системи явищ, що виникають під час діяльності публічної влади і створюють небезпеку вчинення корупційного або пов'язаного із корупцією правопорушення [11, с. 36-37].

На наш погляд, під корупційним ризиком у сфері праці слід розуміти сукупність негативних факторів, що виникають на підприємстві незалежно від форми власності і виступають передумовою для вчинення корупційного правопорушення чи правопорушення, пов'язаного з корупцією.

Серед робіт науковців можна знайти велику кількість досліджень стосовно причин виникнення та розвитку корупції. На думку В. Побережного та В. Бутенко, основними корупційними ризиками $\epsilon$ : зрощування державного апарату з підприємницькими та комерційними структурами, формування їхніх ділових відносин поза межами правового поля; ставлення громадськості до існування корупції та сприяння їі розвитку; складність урядової структури бюрократичних процедур; низький рівень оплати праці та надання соціальних послуг; лобіювання прийняття та зміни нормативно-правових актів $[12 ; 13]$.

Про причини, пов'язані з корупційними ризиками безпосередньо в Україні, наголошує М. Хавронюк. По-перше, це кумівство, тобто політичне заступництво і таємні домовленості, політичний протекціонізм, внаслідок чого формуються особисті стосунки, що ослабляють механізми контролю та запобігання корупції; по-друге, це занадто слабкий розвиток політичної свідомості суспільства, його громадянських інституцій, що унеможливлює громадський контроль. Окрім цього, науковець стверджує про так зване почуття безкарності, яке породжує недостатня визначеність, непослідовність у проведенні антикорупційної політики. Попри це, особливими проблемами виявляються наявність у посадових осіб надто широких розпорядчо-дозвільних (дис- 
креційних) повноважень для прийняття рішень на свій розсуд, що дає їм можливість створювати зайві ускладнення, перебільшувати свою роль у вирішенні питань, пов'язаних зі зверненнями громадян; поширеність у кадровій політиці випадків заміщення посад та прийняття на роботу не на підставі ділових і моральних якостей, а через знайомство за колишньою роботою, особисту відданість, близькість політичних уподобань; відсутність у більшості установ, підприємств та організацій окремих підрозділів або спеціально призначених працівників, на яких покладаються обов'язки організації роботи щодо запобігання корупційним та іншим посадовим правопорушенням [14, с. 47-53].

У цьому аспекті неможливо не згадати таке поняття, як «непотизм», що полягає в негативному впливі родинних зв'язків на службові (трудові) відносини службовців (працівників) i на якість їхньої службової (трудової) діяльності, у можливому зловживанні службовим (посадовим) становищем в інтересах родичів. Непотизм являє собою одну з форм прояву корупції, за якої особисті інтереси особи, засновані на їі родинних зв'язках (властивостях), протиставляються громадським, державним та іншим інтересам у вигляді зловживання посадовим (службовим) становищем. Негативний вплив родинних відносин на об'єктивність і неупередженість i якість виконання трудових обов'язків, а також конфлікт інтересів і його дозвіл за участю працівників $\epsilon$ причинами, що зумовили необхідність правового регулювання протидії непотизму в трудових відносинах.

Зазначене регулювання було закріплено у ст. 25-1 КЗпП і обмежує спільну роботу родичів на одному підприємстві, у цьому разі визначальною $€$ роль власника, який наділений правом запровадження такого обмеження [15, ст. 25-1].

Проаналізувавши позиції науковців та провівши власні дослідження, доречно стверджувати, що серед основних передумов, що виступають джерелом для виникнення та існування корупційних ризиків на підприємстві, є: низький рівень громадської правосвідомості; правовий нігілізм; низький рівень та незадовільні умови праці окремих категорій працівників; неоднозначний зміст законів та підзаконних актів, через що їх зміст може тлумачитись помилково; зниження довіри населення до влади; професійна некомпетентність працівників та роботодавців; непотизм.

Поглиблюючись безпосередньо у систему методів боротьби із таким суспільно негативним явищем, як корупція, необхідно виходити, що боротьба з корупцією поділяється на два рівні, зокрема на дії імперативного характеру (протидія) та дії превентивного характеру (запобігання). Така боротьба має виходити та ґрунтуватися на правових принципах і здійснюватися державою шляхом залучення до цього відповідних суб'єктів. Безперечно, провідну роль у цій боротьбі відіграє саме превентивний метод.

Запобігання корупції - це недопущення, завчасне відвернення корупційних діянь. На сучасному рівні запобігання корупції здійснюється шляхом різного роду заборон, правил та обмежень, мета яких - запобігати вчиненню корупційних правопорушень та правопорушень, пов'язаних з корупцією. Зазначені правила, заборони та обмеження містяться у законах та підзаконних актах.

Доречним видається поділяти механізм запобігання корупції на нормативний та інституційний складники.
Так, основним нормативно-правовим актом антикорупційного законодавства в Україні визнається Закон України «Про запобігання корупції». Іншими актами, що утворюють основу антикорупційної політики, $є:$ Конституція України; Кодекс України про адміністративні правопорушення (розділ 13-А, що визначає відповідальність за правопорушення, пов'язані із корупцією); Цивільна конвенція про боротьбу з корупцією (ратифікована Законом України від 16 березня 2005 року № 2476IV); Кримінальна конвенція про боротьбу з корупцією (ратифікована Законом України від 18 жовтня 2006 року № 252-V); Конвенція ООН проти корупції (ратифікована Законом України від 18 жовтня 2006 року № 251-V) тощо.

Інституційний складник проявляється у створенні відповідних уповноважених суб'єктів, які обов'язково утворюються в органах державної влади, місцевого самоврядування, підприємствах та установах і здійснюють контроль за додержанням антикорупційного законодавства.

Розглядаючи у правовому контексті протидію корупції, необхідно визнати ії вторинність щодо запобігання. О. Онищук визначає протидію корупції як скеровування діяльності спеціально визначених суб'єктів публічної адміністрації проти будь-яких розпочатих корупційних проявів [16, с. 36]. Поняття запобігання корупції $\epsilon$ ширшим, ніж протидія. Це виявляється у тому, що повноваженнями щодо запобігання корупційним діянням наділена велика кількість державних і недержавних суб'єктів, а компетенція щодо протидії корупції $\epsilon$ вичерпною, при цьому посадові особи і підрозділи Національної поліції, Національне агентство з питань запобігання корупції, Національне антикорупційне бюро зобов'язані займатись як запобіганням, так і протидією корупції.

Надаючи рекомендації щодо засобів запобігання і протидії корупції, слід акцентувати увагу на двох загальновизнаних механізмах боротьби із корупцією: сінгапурському та європейському (шведському). Перший - передбачає запровадження суворої юридичної відповідальності та контролю за корупційними суб'єктами (більшою мірою найвищого рівня). Другий - послаблення обмежень і заборон у суспільстві, зокрема, йдеться про зменшення контролю та тиску на економіку, розширення свободи слова, посилення прозорості у публічних справах.

Екстраполюючи зазначені механізми на українську державу в добу розвитку євроінтеграційних процесів, можна стверджувати, що найбільш вдалим для нашої країни стане комплексне застосування зазначених методів. Йдеться про розумне поєднання суворої юридичної відповідальності з послабленням обмежень і заборон. 3 одного боку, особа не буде вчиняти корупційних правопорушень під загрозою суворої відповідальності (досвід Сінгапуру), а з іншого - тому що не буде бачити у цьому потребу (європейський досвід).

Поміж цього позитивно відобразяться на антикорупційній політиці такі заходи, як посилення гарантій державного захисту осіб, що сприяють боротьбі із корупційними діяннями, чітке розмежування повноважень між органами, завдання яких - провадити антикорупційну політику в Україні, задля уникнення їх дублювання, широке залучення громадян до боротьби з корупцією, тобто збільшення тиску на потенційних правопорушників засобами соціального впливу. 


\section{Проблеми трудового права та права соціального забезпечення}

Необхідно визнати той факт, що законодавець зі свого боку здійснив спробу упорядкувати та поліпшити антикорупційну політику. 3 огляду на це потребують роз'яснення деякі легальні поняття, що лежать в основі корупційних ризиків. Ідеться про поняття «корупційне правопорушення» та «правопорушення, пов'язане із корупцією» Так, на законодавчому рівні у ч. 1 ст. 1 Закону України «Про запобігання корупції» надається визначення корупційному правопорушенню, а саме як діянню, що містить ознаки корупції, вчинене особою, зазначеною у ч. 1 ст. 3 цього Закону, за яке законом встановлена кримінальна, дисциплінарна та/або цивільно-правова відповідальність [6]. Звідси можна дійти висновку про класифікацію корупційних правопорушень, зокрема на кримінальні, цивільні та дисциплінарні. Кримінальні правопорушення - це злочини, вичерпний перелік яких міститься в Особливій частині Кримінального кодексу України [17].

Цивільні корупційні правопорушення, як правило, випливають із цивільно-правових відносин і містяться у Цивільному кодексі України. Відповідальність настає з моменту правопорушення у зв'язку із заподіянням моральної або матеріальної шкоди.

Говорячи про корупційні правопорушення у сфері праці, то юридичною підставою для відповідальності тут слугують такі нормативно-правові акти, як Кодекс законів про працю та дисциплінарні статути підприємств, установ та організацій. Особливістю цього виду правопорушень $\epsilon$ те, що відповідальність за вчинення дисциплінарних корупційних правопорушень накладається відповідною адміністрацією підприємств, установ, організацій. При чому суб'єкт, який уповноважений притягати особу до дисциплінарної відповідальності, мусить діяти відповідно до правил внутрішнього трудового розпорядку, в порядку підпорядкованості та відповідно до дисциплінарних статутів i положень [15]. Таким чином, дисциплінарна юридична відповідальність встановлюється у зв'язку із порушенням трудової та службової дисципліни, а якщо у них міститься корупційний склад, то він визначається Кодексом законів про працю. Зокрема, серед додаткових підстав для розірвання трудового договору з ініціативи власника або уповноваженого ним органу з окремими категоріями працівників за певних умов КЗпП визначає перебування всупереч вимогам Закону України «Про запобігання корупції» в прямому підпорядкуванні у близької особи [15].

У зазначеній класифікації корупційних правопорушень відсутні адміністративні правопорушення. Причиною цього $\epsilon$ віднесення законодавцем цієї категорії до правопорушень, пов'язаних із корупцією. Кодекс України про адміністративні правопорушення чітко окреслює ті правопорушення, за які передбачена адміністративна відповідальність, їх перелік міститься у главі 13-А кодексу (Адміністративні правопорушення, пов'язані з корупцією). Це порушення обмежень щодо сумісництва та суміщення з іншими видами діяльності, порушення встановлених законом обмежень щодо одержання подарунків, порушення фінансового контролю, порушення вимог щодо запобігання та врегулювання інтересів невжиття заходів протидії корупції та інші [18].

Зазначені діяння, хоча і не мають ознак корупції та, попри це, напряму пов'язані із нею. Протиправні діяння цього виду можуть викривати та приховувати коруп- ційні правопорушення та є свідомим актом особи, тобто вчиняються умисно.

Засоби успішної боротьби із корупцією передбачають взаємоузгоджену взаємодії органів державної влади на всіх рівнях. На жаль, досвід показує, що Україна ще не досягла такого етапу розвитку, за якого взаємодія між органами влади призводила 6 до значних зрушень в антикорупційній політиці. Виходячи з цього, вкрай необхідним видається застосування тих механізмів боротьби із корупцією, що успішно застосовуються і функціонують у інших країнах світу.

Серед таких можемо виділити поділ корупції на види (банківська поліцейська, політична) та рівні (така, що становить особливу небезпеку для суспільства та повсякденна) та їх нормативне закріплення, взаємодія з міжнародними антикорупційними органами, створення ефективного та незалежного органу по боротьбі 3 корупцією [19; 20, с. 125; 21, с. 18-19; 22].

Висновки. Таким чином, визначившись із поняттям «корупція», виявивши ії суспільно негативні наслідки та причини вчинення корупційних дій, нами сформульовано поняття корупційних ризиків у сфері праці, під якими слід розуміти сукупність негативних факторів, що виникають на підприємстві, установі, організації незалежно від форми власності і виступають передумовою для вчинення корупційного правопорушення чи правопорушення, пов'язаного з корупцією.

Аналіз нововведень в антикорупційному законодавстві України говорить про те, що законодавцем урегульовано чимало проблемних питань, пов'язаних із корупцією, але наявні механізми боротьби повною мірою не забезпечують істотних зрушень у правовому регулюванні корупційних діянь, про що свідчить негативна антикорупційна динаміка країни. Основною причиною існування корупційних ризиків та низького рівня антикорупційної динаміки в сфері трудових відносин зокрема, з одного боку, лишається людський фактор: професійна некомпетентність, малорозвинена громадська правосвідомість, правовий нігілізм, з іншого - недостатня увага з боку законодавця до наявних у суспільстві проблем: низький рівень заробітної плати працівників, непотизм, незадовільні умови праці, невизначеність або відсутність нормативних актів, що регулюють певну сферу суспільних відносин, зокрема професійних, наявність чималої кількості державних органів, що здійснюють контроль за корупційними справами з однаковими дубльованими повноваженнями.

3 огляду на це доречним є використання зарубіжного досвіду та правових механізмів запобігання корупційним ризикам. Так, найбільш вдалим для України видається застосування імперативного підходу (досвід Сінгапуру) із запровадженням суворої юридичної відповідальності за корупційні діяння у комплексі з послабленням певних обмежень і заборон у суспільстві. Крім цього, на увагу заслуговують ті механізмі боротьби із корупцією, які використовують у своїй антикорупційній політиці більшість розвинених країн світу. Дієвим засобом боротьби з корупцією лишається засіб соціального впливу, таким чином, залучення громадян, які не $\epsilon$ представниками державних органів, до антикорупційної діяльності створить позитивну атмосферу у межах підприємства, що позитивно відобразиться на антикорупційній динаміці країни загалом. Окрім цього, вкрай необхідним $є$ налагодження міцної співпраці з Європейськими антико- 


\section{та права соціального забезпечення}

рупційними органами з метою залучення важливого досвіду боротьби із корупційними ризиками і перенесення його в площину національного законодавства.

\section{Література}

1. Офіційний сайт Transperency International в Україні. URL: https://ti-ukraine.org/research/indeks-spryjnyattyakoruptsiyi-2018/1.

2. Шемшученко Ю.С. Юридична енциклопедія. Т. 3. Київ.1998. 216 с.

3. Потебня О.О., Білодід І.К. Словник української мови: в 11 томах. Т. 4, 1973. 302 с.

4. Голубовська І.О., Шовковий В.М., Лефтерова О.М. та ін. Багатомовний юридичний словник-довідник. Київ : Видавничо-поліграфічний центр «Київський університет». 2012. 543 c.

5. Ревак І.О. Корупція: теоретико-методологічні засади дослідження : монографія. Львів : ДУВС. 2011. 220 с.

6. Мельник М.І. Корупція: сутність, поняття, заходи протидії. Київ : Атіка, 2001. 304 с.

7. Куракин А.В. Коррупция : понятие, характеристика и формы проявления в сфере государственного управления. Современное право. 2002. № 3. С. 36.

8. Серьогін С.М. Державний службовець у відносинах між владою і суспільством : монографія. Дніпропетровськ : ДРІДУ НАДУ, 2003. 456 с.

9. Про запобігання корупції : Закон України від 14.10.2014 № 1700-VII. Відомості Верховної Ради України. 2014. № 49. Ст. 2056.

10. Бугайчук К.Л. Корупційні ризики: поняття, класифікація, методологія оцінки, заходи усунення. 36. тез дon. V Міжнар. наук.практ. конф. (м. Харків, 31 берез. 2017 р.). МВС України, Харків. нац. унт внутр. справ; Кримінол. асоц. України. Харків : ХНУВС, 2017. С. 3940.

11. Заїка К.П. Корупційні ризики: поняття та засоби їх мінімізації. Актуальні проблеми правознавства. 2018. № 2. C. 35-38.

12. Бутенко В.І. Природа і причини корупції в Україні. Перспективи розвитку та протидії корупції. URL: http: / / www.jimagazine.lviv.ua/ji-junior/N32-1/butenko.htm.

13. Побережний В.В. Сутність та причини корупції в системі органів державної влади. URL: http://academy.gov.ua/ej/ej12/txts/10pvvodv.pdf.
14. Калмиков Д.О., Сінченко Д.В., Сорока О.О., Хавронюк М.І., Шведова Г.Л. Запобігання корупції: методичні рекомендації для місцевих активістів / за заг. ред. М.І. Хавронюка. Київ : ФОП Москаленко О.М., 2017. 242 с.

15. Кодекс законів про працю України: затв. Законом УРСР від 10.12.1971 р. № 322-VIII. Відомості Верховної Ради УРСР. 1971. № 50 (Додаток). Ст. 375.

16. Онищук 0.О. Концептуальні засади запобігання та протидії корупції в Україні. Адвокат. 2010. № 9. С. 35-37.

17. Кримінальний кодекс України : Закон № 2341-ІІІ від 05.04.2001. Відомості Верховної Ради України. 2001. № 25-26. Ст. 131.

18. Кодекс України про адміністративні правопорушення : Закон № 8073-Х від 07.12.1984. Відомості Верховної Ради УРСР. 1984. Додаток до № 51. Ст. 11221.

19. Підбережник Н.П. Антикорупційна політика в країнах Західної Європи: досвід для України. Ефективність державного управління. 2013. Вип. 37. С. 123-132.

20. Ільєнок Т.В. Зарубіжний досвід адміністративноправової протидії корупції. Юридична наука. 2012. № 12. С. 42-51.

21. Беглиця В.П. Досвід європейських країн щодо формування антикорупційної стратегії. Наукові праці чорноморського державного університету імені Петра Могили комплексу «Києво-Могилянська академія». Серія «Державне управління». 2015. Т. 263, Вип. 252. С. 17-23.

22. LOI No 2016-1691 du 9 décembre 2016 relative à la transparence, à la lutte contre la corruption et à la modernisation de la vie économique. URL: https: / / www.legifrance.gouv.fr/jo_pdf.do?id= JORFTEXT000033558528.

Красюк Т. В., кандидат юридичних наук, асистент кафедри трудового права Начіонального юридичного університету імені Ярослава Мудрого

Зал Д. О., студент

Начіонального юридичного університету імені Ярослава Мудрого 